\begin{tabular}{c} 
International Journal of Engineering \& Technology, $7(3.21)(2018) 487-490$ \\
International Journal of Engineering \& Technology \\
SPC \\
Website: $\frac{\text { www.sciencepubco.com/index.php/IJET }}{\text { Research paper }}$ \\
\hline
\end{tabular}

\title{
The Influence of Parenting and Socialization Religious Values for Early Prevention Behavior toward Lesbian, Gay, Bisexual, and Transgender
}

\author{
Ieke Sartika Iriany ${ }^{1}$, RostienaPasciana $^{2}$ \\ ${ }^{1,2}$ Department of Public Administration, Universitas Garut, Indonesia \\ *Corresponding author E-mail: sartikaieke@gmail.com;
}

\begin{abstract}
This research motivated by the rise of deviant behavior news by various media, the deviant behavior including LGBT (Lesbian, Gay, Bisexual, and Transgender) that lately become a hot actual topic. The purpose of this study is to discuss the influence of parenting and socialization of religious values in attempt to avoid behavior prevention of lesbian, gay, bisexual, and transgender. The study used the quantitative approach with survey technique and the parents Vocational High School (SMK) Class XI in Garut Regency, West Java Province of Indonesia as its population. Seventy-two people determined through a simple random sampling. The data collection techniques used questionnaires, observations and interviews for primary data and secondary data obtained from a review of the documentation and reports from competent agencies such as the Special Services Police Garut Unit, women's and children Committee (KP2A). Data analysis performed in non-parametric statistics that would examine the influence of the independent variables: parenting and socialization of religious values, on the dependent variable: early prevention behavior LGBT. According to the research, it concluded: parenting is in the criteria fairly well. Socialization of religious values are in the criteria fairly well. Early prevention of behavior LGBT is in the criteria well. The results of the research hypothesis testing, both the main hypotheses and sub-hypotheses indicate that parenting and socialization of religious values are significant and have positive effect on early prevention LGBT behavior. The conclusion from the result of the discussion and the theories used, it found that there was an ideal democratic parenting to form the early prevention of LGBT behavior within teenagers in vocational high school. The result of the research provides input to education policy makers in order to include subjects concerning the manners of upbringing and socialization models of religious values. Particularly, to conduct affirmative movement through brochures, pamphlets about the importance of parenting. Benefits theoretically research for the development of knowledge of the parents and practically an education policy maker.
\end{abstract}

Keywords: LGBT(Lesbian, Gay, Bisexual, and Transgender); parenting; religious values socialization.

\section{Introduction}

The phenomenon of movement for Lesbian, Gay, Bisexual and Transgender (here in after referred to as LGBT) in Indonesia in recent years have been more and more alarming. Perpetrators of sexual orientation irregularities initially hide his identity; today they have more courageto show their existence in public spaces. The Liberal leader is in the vanguard of providing support to the action, which are increasingly massive and structured. On behalf of Human Rights (HAM) and the free flow of liberalism are at the forefront of defending LGBT. Even their struggle takes place through three channels; academic, political and social movements. Indonesia is currently at the emergency LGBT. There has been growing organizational phenomena constructed of the pro-LGBT rainbow as a symbol of 'diversity' sexual orientation since 2006; this organization aims to be a representation of the LGBT community to influence social norms and perceptions regarding sexual orientation. Actions taken including Rainbow Run and speeches at the Hotel Indonesia intersection on Sunday (17/05/2015) chanted equality and elimination of discrimination on LGBT people within the framework of the International Day against Homophobia and Transphobias (IDAHOT) Kompas News, 2015). Not only in Jakarta, Yogjakarta supported LGBT groups in the organization People Like Us One Heart (PLUSH) celebrates Transgender Remembrance Day on Friday (20/11/2015) with staged in Yogyakarta Police Office (News Jakarta Post, 2015).

Similarly in other cities like Malang and Semarang also appeared to express support student activities on LGBT, although later canceled by the authorities. Pro-LGBT organizations are widespread and have a network including at foreign institutions often act as funders. Deconstruction of Moral Relativism variety of sexual orientation by pro-LGBT movement is rooted in the argument of moral relativism.

This kind of alarming condition makes many people wary, indicating troubles for the parents who should play a role in the dissemination of religious values, morals that shape the children behavior, so the tendency of having LGBT deviant behavior will be preventedearly on. Indonesian Ulama Council (MUI) has issued a MUI Fatwa No. 57 of 2014 on Lesbian, Gay, sodomy, and sexual abuse. In this fatwa, MUI forbid LGBT because it is categorized as "a crime". 
The family is an important element in determining the merits of the society, thus the parenting determines the child's behavior. Because parenting is a whole interaction between parents and children, parents stimulate the child to change behavior, knowledge, and values that are the most appropriate, so that children can be independent, grow up and develop healthy and optimal. Parenting pattern is a pattern of behavior applied to children that is relatively consistent over time. This pattern of behavior is perceived by the children, in terms of negative and positive. Parenting applied in each family is different; it depends on the view of each parent (1).

There are several cases of sexual abuse against 15 elementary schools (SD) in the District Bayongbong Garut, West Java (Gala Media Local News | Tuesday, March 1st, 2016 | 15:27 GMT). According to the Program Manager National AIDS Commission (KPA) Garut Guntur, and based on the estimation of the Ministry of Health in 2012, the number of the gay community in Garut reaches about 12,000 people, and transvestites around 135 people. While the mapping of the NAC in 2015, there are 109 hotspot or gay community hangout known in Garut, with the number of gay recorded about 3,200 people. From many gay communities, and transvestites, there were 25 people gay, and $11 \mathrm{HIV}$-positive transgender people. Media Gala on Sunday (14/2).

Based on the raised problems on the background, the writer is interested in conducting a research entitling: "The Effect of Parenting and socialization of Religious Values Early Prevention Behavior against LGBT"

\section{Literature Review}

LGBT behavior can occur because of parenting and wrong learning patterns, both the education given by the parents or the education and the impacts of the surrounding environment or external factors in general. Both of these factors should be equally paid attention. Internal factors relate to the parental education, for example, in some cases there are many parents who wanted to have daughters, but then the mother gave birth to a boy. If these parents do not understand religion, and do not accept the fact of having a boy for their child, they will treat their son like a girl. This kind of attitude of parenting is considered to be a big mistake, and it is not justified in Islam, because it can cause a child to live their lives contrary to the sacred nature as a man or a woman.

In social life, the family is a social sub-system, "the family is a core element in the social structure, the main position of each family are as personal liaison with the larger social structure" (2). The family is the primary agent and the most important aspect in facing social change, especially through the 'role' of each member of the family. The position of a person in a family plays important roles in determining the different functions in the family. These different functions aimed at achieving the purpose of the family as a whole, structure and function are affectedby the values of religion, culture, and norms were used as basis in the system.

There are several patterns of parenting to children's character formation, namely:

\section{1) Authoritarian Parenting Pattern}

It has some characteristics such as the power of parents is dominant over the child, the child is not recognized as an individual, control over the child's behavior is very tight, parents punish the child if the child does not obey

\section{2) The Democratic Parenting Style}

There are some characteristics of this parenting style such as there is cooperation between the parent and child, the child is recognized as a person, there aresome directions and guidance from parents, there are not rigid parent controls over the children.

\section{3) The Permissive Parenting Pattern}

This parenting pattern shows the dominance ofthe children; gives loose attitude or freedom and less control and parental attention to the children; indicates no guidance and direction from the parents.
In this study, the authors define Democratic Parenting, as a theoretical basis. Many parents do not realize that attitude and parenting applied to children have contributed to the formation of dependency, lack of confidence and excessive worries, for example, the attitude of over protective parents against children will cause them to be unconfident, uncourageous, and dependent. The children are never permitted or encouraged to be independent. As a result, they will grow up to be spoiled, always dependent on the care and help of parents, fearful, whiny, and not able to solve their own problems.

These continuous children dependencies are aimed at making the children needed (meaningful and useful) and considering the children as "eternal" friends. In fact, behind the child's dependence towards the parent, the parents expect some kind of "approval" from their child. As a result, they cannot break away when the child must become independent and it becomes difficult for the child to grow into a mature individual. Similarly, the tendencies of LGBT behavior were partly due to an error committed by the parents on parenting pattern. Because of this matter, it must be questioned whether there is a correlation between parenting and socialization of religious values towards the tendency of LGBT behavior or not.

The democratic parenting based on the theory of convergence (3), stated that human development depends on factors from inside and outside, meaning that education in this regard that parenting is omnipotent. Therefore, parenting should be balanced, the children must not be allowed to act too freely, but the parents shouldnot dominate children. Parenting is about guiding the children towards the better development.

Democratic parenting is parenting pattern characterized by the recognition of parents towards the child's ability, the child has the opportunity not to always depend on the parents. Parents give freedom to the child to choose what is best for them; listen to child's opinion, involve the child in the discussion, especially concerning the child's life. Children get the opportunity to develop their internal controls so that little by little they can practice to be responsible to themselves. They also possess the opportunity to involve and to participatein managing their lives. In the family, the parents' part in parenting should realize the role or responsibility of educating and parenting their children / foster children. Indicators of democratic parentingas follows: (1) discipline (2) togetherness and (3) mutual cooperation.

According to (4) socialization is divided into two kinds; first, the primary socialization, the socialization process that occurs when a person's age turns five. In this phase, the children are given the knowledge of people who are in the social environment of their family members. They are given the ability to recognize themselves and their own identity, which distinguishes between themselves and others. It is very necessary, especially for shaping the children's character in the next age with particular regard to the guidance code of conduct to the children, so that later the children own personality and the correct role to put them in a social environment

Second; secondary socialization: the socialization that takes place after primary socialization, which happens when the children turn four. If the process of primary socialization dominant role of family is very strong, but in the secondary socialization process of recognition of the code of conduct is the social environment, such as playmates, peers, schools, the other older people until the process of introduction of the customs prevailing in the social environment. Individuals gain a variety of experiences from the social environment. There may be differences in the behavior patterns that exist between the social and family environment. In this phase, the children begin to identify, especially identifying patterns in the social environment outside the family.

In the process of socialization, there are enforced values, according to McGuire (5), the value is the driving force in life, which gives meaning to one's actions. Human beings have a certain value system form. This value system is considered meaningful for them. This system is formed through a process of learning in socialization. 
'Religion' value is the most important thing.The religion according to (6) that whatever religion is, it is an expression of a form of dependence on the strength of the force outside oneself that can be regarded as a spiritual force or moral strength. Religious values consist of two words, "values", and "religious". Value means the belief that makes people act based on his choice. Thus, the value can be defined as a certain characteristic contained in something that is considered as valuable and respectable matters. This characteristic makes anything becomes wanted and loved, well loved by one person or group of people, for example; "nasab" for respectable people that have high value, knowledge has a high value for ulama and courage has a value that is loved for the government and so forth. While the religious are the things that are religious; therefore, the values of religious in terms of Islam are the values reflected from either in the form of patterns of belief (Aqeedah), patterns of thought and action (worship) and attitude (Akhlaq). One of the behaviors that deviate from the value of religion is sexual perversion, such as by (7) Sexual Deviation is sexual behavior that is not commonly done. Example:

a. Adultery is sexual relations outside marriage.

b. Lesbianism is a sexual intercourse committed by fellow women.

c. Homosexuality is a sexual intercourse committed by a fellow man.

d. Cohabiting is to live as husband and wife without marriage.

e. Sodomy is sexual intercourse through the anus.

f. Transvestitism is satisfactory sexual desire by wearing clothes of the opposite sex.

g. Sadism is sexual satisfaction by hurting others.

h. Pedophilia is satisfactory sexual desire by having sexual contact with children.

Parents play a very important role in the dissemination of religious values in the family environment, so that the causes of deviant behavior of children are often directed at the parenting mistakes. The roles of parents largely determine the success of the socialization of their children. To shape Muslim personality are the parents' role. Muslim personality refers to all good aspects of the personalities, good attitude and behavior, kind soul, and devotion that reflect one's recumbence to God. In addition to transfer the means of religious values in the younger generation, dissemination of religious values also aims in the context of maturation of personality. Indicator of maturation is responsibility. This means that the responsibility to preserve the values of good faith in religious life, personal, family, community and country.

The theory of functionalism sees religion as a special form of culture, which influence its followers' behavior both physically and mentally, hence the social system for the most part consists of the rules established by religion. Functionalism, as a principle, flows deliberately and provides a case for itself as it emphasizes on what it seeson religion. It sees the religion from its function; considered as another institution, which has task (function) to make the community works properly in local, regional, or national (8).

Human believe that with a strong faith, religion has the definite ability in helping humans. Humans give certain specific functions to religion (1) The educative function, (2) the salvation function, (3) social control, (4) cultivating unity function and (5) the transformative function.

\section{Methodology}

The method used in this research is descriptive analysis. Descriptive research has a purpose to describe individuals' or certain groups' characteristics, condition, symptoms, and to determine the frequency of certain relationship among particular symptoms to others that exists in society. Based on the previous statement, it expects that descriptive method with survey technique used on this research is able to unfold the phenomenon that is systematically studied to achieve the truth from the issues researched. a. Parenting pattern (X1) in this research interpreted as the parents' way to educate their children directly or indirectly with democratic parenting pattern dimension which has indicators that include: (1) discipline (2) togetherness and mutual cooperation b. Religious value socialization (X2) in this research interpreted as activity process that has purpose to embrace all the parties to obey the applicable values and rules with religious norm dimension. Religious norm dimension has indicators include: (1) socialization agent (2) socialization pattern (3) faith pattern (aqidah), (4) action mindset (Ibadah), (5) attitude (Akhlaq).

c. LGBT deviant behavior early prevention in this research interpreted as all kinds of activities that prevent LGBT deviant behavior from early stage based on religious value and social value behavior. The indicators are:

a. primary deviant behavior

b. secondary deviant behavior

Measuring instrument used in this research was structured questionnaire that contains several question items with alternative answers. Variables measurement levels in this research is ordinal and the answer categories consist of five answer categories that oriented to Likert scale.

The population in this research was the parents of second grader students in light vehicle engineering major and agricultural major at SMK (vocational high school) four, Garut Region. The number of population is 260 people. Seventy-two people determined through a simple random sampling method and determined by Slovin formula.

Hypotheses test conducted by testing main hypothesis and sub hypothesis using two tailed Rank Spearman correlation with 5\% alpha.

\section{Results and Findings}

Analysis results conducted together simultaneously showed that parenting independent variable (X1) and the socialization of religious values (X2) with the dependent variable LGBT Behavior Early Prevention (Y) have a positive and strong relationship level, up to $74.2 \%$, and epsilon by $25.8 \%$. There were found some other influential variables, which are not included in this study, such as the role of teachers in schools, children's playingenvironment, and curriculum.

Partially in sub hypothesis, the results showed that the parenting early prevention behaviors affect the Lesbian, Gay, Bisexual, and Transgender (LGBT) are up to $53.43 \%$ and $46.57 \%$ influenced other factors that are not researched by the authors. This shows that in terms of parenting, in sufficient criteria, it indicates that respondents use parenting democratic through discipline, yet there are still problems in the way of instilling cooperation responsible, such as intensive communication between the child and other family members, orally and in writing, the child is less able receives its problems

While socialization Religious Values Early prevention behaviors affect the Lesbian, Gay, Bisexual and Transgender (LGBT) are up to $45.83 \%$ and $54.17 \%$ influenced by other factors, which were not observed by the authors. Socialization of religious values and early prevention of LGBT are categorized as fair criteria. The data indicates that parents should always introduce a sense of gratitude for what God has given, but there are still obstacles in providing assurance behavior of their children.

The results of the research hypothesis testing, both the main hypotheses and sub-hypotheses, indicate that the Parenting and socialization of religious values has a real and positive effect on the prevention of early behavior of Lesbian, Gay, Bisexual and Transgender (LGBT)

\section{Conclusion and Recommendations}

The results of the research hypothesis testing, both the main hypotheses and sub-hypotheses, indicate that the Parenting and socialization of religious values has a real and positive effect on the 
prevention of early behavior of Lesbian, Gay, Bisexual and Transgender (LGBT). Parenting model applied in this study is a model of democratic parenting, but parents should further optimize the discipline in the democratic parenting by teaching cooperation and granting more responsibility in the activities at home; therefore, children can understand the meaning of discipline.

In the socialization of religious values, parents should always introduce their children a sense of gratitude for what God has given in order to motivate them to accept their existence. Besides, those parents must be wise in addressing the problems of deviant behavior in the children's school environment.

Recommendations from the results of this study were (1) the need to follow up on the results of this study, by examining the role of teachers in the prevention of behavioral Lesbian, Gay, Bisexual, and Transgender (LGBT), (2) recommendations to the education policy makers to load a lesson about parenting and socialization model of religious values. In particular, it is necessary to perform an affirmative movement through brochures, pamphlets about the importance of parenting. Theoretically,this research might be beneficial for the development of parenting knowledge and practical benefits for education policy makers.

\section{Acknowledgement}

The researchers are grateful and honor the social science and politics faculty of postgraduate program, Department of Public Administration Garut University who always support the researchers to finish this research.

\section{References}

[1] Petranto I. Buku Ajar Konsep Dasar Keperawatan Anak. Jakarta: EGC; 2006.

[2] Horton PB, Hunt CL. Sosiologi. 1, editor. Jakarta: Erlangga; 1999.

[3] Dickerson AR. Symbolic Convergence Theory. In: Kaid LL, editor. In Encyclopedia of Political Communication. Thousand Oaks: Sage Publications; 2008

[4] Goode WJ. Sosiologi Keluarga. Jakarta: Bumi Aksara; 2007.

[5] McGuire TG. Setting prices for new vaccines (in advance) International journal of health care finance and economics. 2003;3(3):207-24

[6] Kaplan D, Manners AA. Teori-Teori Budaya. Yogyakarta: Pustaka Pelajar; 2000.

[7] Addler, Mortimer, Jerome. Editors of Encyclopædia1952.

[8] Puspitohendro. Sociology of Religion. Jakarta: Kanisius 1983

[10] Madjid N. Masyarakat Religius. Jakarta: Paramadina; 2010.

[11] Kamus Besar Bahasa Indonesia. Jakarta: Balai Pustaka; 1988

[12] Siahaan JMS. Perilaku Menyimpang: Pendekatan Sosiologis. Jakarta: Indeks; 2009.

[13] The Consise Oxford Dictionary of Current English. Oxford: Oxford University Press; 1982. p. 293.

[14] Surya M. Bina Keluarga. Semarang: Aneka Ilmu; 2003.

[15] Surya M. Dasar-dasar Konseling Pendidikan: Konsep dan Teori. Yogyakarta: Kota Kembang; 1988.

[16] Shapiro CA. Supporting Residential Student Organization Advisers: A 21st Century Adviser Training and Development Program. ProQuest. 2013;73(07).

[17] Paul H. Psikologi Populer, Mendidik Anak dengan Berhasil. Jakarta: Publisher; 1993 